\title{
Performance of Holstein x Gyr dairy cows fed hydrolyzed sugarcane-based diets
}

\section{Desempenho de vacas Holandês $x$ Gir alimentadas com dietas baseadas em cana de açúcar hidrolisada}

\author{
Mariana Magalhães Campos ${ }^{1}$; Ana Luiza da Costa Cruz Borges²; \\ Carlos Giovani Pancoti ${ }^{3}$; Ricardo Reis e Silva ${ }^{4}$; Tainá Silvestre Moreira \\ Fernando César Ferraz Lopes ${ }^{6 *}$
}

\begin{abstract}
Twelve multiparous 7/8 Holstein x Gyr dairy cows were fed diets based on chopped sugarcane supplied in natura (control) or after being hydrolyzed (fresh matter basis) for $24 \mathrm{~h}$ with $0.5 \%, 1 \%$ or $2 \%$ calcium oxide $(\mathrm{CaO})$. The voluntary consumption and digestibility of dietary nutrients, milk production and composition, and feeding behavior of cows were evaluated. A switchback design with three periods, four treatments and three blocks was used. The linear and quadratic effects of the treatments were analyzed using orthogonal contrasts, and the effects were considered significant when $\mathrm{P} \leq 0.05$. Compared to the that in the control treatment, the Ca concentration increased by $297 \%, 570 \%$ and $1,083 \%$ in the diets including sugarcane hydrolyzed with $0.5 \%, 1 \%$ and $2 \% \mathrm{CaO}$, respectively, while the respective $\mathrm{Ca}: \mathrm{P}$ ratios were 6.58:1, 10.70:1 and 19.77:1 (control Ca:P ratio: 1.55:1). The hydrolysis of sugarcane with increasing amounts of $\mathrm{CaO}$ promoted a linear reduction $(\mathrm{P}<0.01)$ in the intake of dry matter $(\mathrm{DM})$, nonfibrous carbohydrates, crude protein $(\mathrm{CP})$, organic matter $(\mathrm{OM})$, neutral detergent fiber corrected for ash and protein (NDFap) and ether extract. The intake of total digestible nutrients, acid detergent fiber (ADF), lignin, hemicelluloses and cellulose presented quadratic behavior $(\mathrm{P}<0.01)$ in response to increasing $\mathrm{CaO}$ concentrations used for sugarcane hydrolysis. Increases in the amount of $\mathrm{CaO}$ used for sugarcane hydrolysis had no effect on the digestibility of NDFap $(\mathrm{P}>0.05)$, but there were linear reductions $(\mathrm{P}<0.05)$ in the digestibility of $\mathrm{DM}, \mathrm{OM}$ and $\mathrm{ADF}$; the production of milk corrected or not corrected to 4\% fat; and the content of protein, lactose and total solids. Linear reductions $(\mathrm{P}<0.05)$ were also observed in the production of all milk components. Only the milk fat content was not altered $(\mathrm{P}>$ $0.05)$ in response to the inclusion of hydrolyzed sugarcane in the diets. There was no effect $(\mathrm{P}>0.05)$ of sugarcane hydrolysis with increasing amounts of $\mathrm{CaO}$ on the time the cows spent idle, ruminating and feeding, but there was a linear increase $(\mathrm{P}<0.05)$ in the minutes spent ruminating $1 \mathrm{~kg}$ of DM and $\mathrm{NDF}$. Chopped sugarcane hydrolyzed for $24 \mathrm{~h}$ with $0.5 \%$ to $2.0 \% \mathrm{CaO}$ should not be used as exclusive roughage in diets for Holstein $\mathrm{x}$ Gyr dairy cows with an average milk production of $10 \mathrm{~kg} \mathrm{day}^{-1}$.
\end{abstract}

Key words: Alcali. Bovine. Calcium oxide. Digestibility. Feeding behavior. Saccharum officinarum.

\footnotetext{
${ }^{1}$ Pesquisadora, Empresa Brasileira de Pesquisa Agropecuária, EMBRAPA Gado de Leite, Juiz de Fora, MG, Brasil. E-mail: mariana.campos@embrapa.br

2 Prof ${ }^{a}$ Associado, Departamento de Zootecnia, Escola de Veterinária, Universidade Federal de Minas Gerais, UFMG, Belo Horizonte, MG, Brasil. E-mail: analuizavetufmg@gmail.com

3 Médico Veterinário, Dr. em Zootecnia, Agroceres, Agroceres Multimix, Rio Claro, SP, Brasil. E-mail: carlos.pancoti@agroceres. com

4 Prof. Adjunto, Departamento de Zootecnia, Escola de Veterinária, UFMG, Belo Horizonte, MG, Brasil. E-mail: ricreis1@ hotmail.com

5 Bióloga, Dr ${ }^{\mathrm{a}}$ em Nutrição e Produção Animal, Faculdade de Medicina Veterinária e Zootecnia, Universidade de São Paulo, USP, Pirassununga, SP, Brasil. E-mail: taina.tr@gmail.com

6 Analista, EMBRAPA Gado de Leite, Juiz de Fora, MG, Brasil. E-mail: fernando.lopes@embrapa.br

* Author for correspondence
} 


\section{Resumo}

Doze vacas multíparas $7 / 8$ Holândês x Gir foram alimentadas com dietas à base de cana de açúcar picada fornecida in natura (controle) ou hidrolisada (base da matéria natural) por $24 \mathrm{~h} \mathrm{com} 0,5 \%$, $1 \%$ ou $2 \%$ de óxido de cálcio $(\mathrm{CaO})$. O consumo voluntário e a digestibilidade dos nutrientes das dietas, a produção e composição do leite, e o comportamento alimentar das vacas foram avaliados. Um delineamento em switchback com três períodos, quatro tratamentos, e três blocos foi utilizado. Os efeitos linear e quadrático dos tratamentos foram analisados por contrastes ortogonais e diferenças foram consideradas significativas quando $\mathrm{P} \leq 0,05$. Em comparação ao tratamento controle foram observados aumentos de $297 \%, 570 \%$ e $1.083 \%$, respectivamente, nas concentrações de Ca nas dietas com cana de açúcar hidrolisada com $0,5 \%, 1 \%$ e $2 \%$ de $\mathrm{CaO}$, enquanto que as respectivas proporções de Ca:P nas dietas foram de 6,58:1, 10,70:1 e 19,77:1 (controle =1,55:1). A hidrólise da cana de açúcar com quantidades crescentes de $\mathrm{CaO}$ promoveu redução linear $(\mathrm{P}<0,01)$ sobre os consumos de matéria seca (MS), carboidratos não fibrosos, proteína bruta (PB), matéria orgânica (MO), fibra em detergente neutro corrigida para cinzas e proteína (FDNcp) e extrato etéreo. Os consumos de nutrientes digestíveis totais, fibra em detergente ácido (FDA), lignina, hemiceluloses e celulose apresentaram comportamento quadrático $(\mathrm{P}<0,01)$ em resposta ao aumento na inclusão de $\mathrm{CaO}$ na hidrólise da cana de açúcar. $\mathrm{O}$ incremento na quantidade de $\mathrm{CaO}$ na hidrólise da cana de açúcar não promoveu efeito sobre a digestibilidade da FDNcp $(\mathrm{P}>0,05)$, mas houve reduções lineares $(\mathrm{P}<0,05)$ nas digestibilidades da MS, MO e FDA, bem como na produção de leite corrigida ou não para $4 \%$ de gordura, e nos teores de proteína, lactose e sólidos totais. Também houve reduções lineares $(\mathrm{P}<0,05)$ nas produções de todos os componentes do leite, incluindo a gordura, cujo teor, no entanto, não foi alterado $(P>0,05)$ em resposta à inclusão de cana hidrolisada nas dietas. A hidrólise da cana de açúcar com quantidades crescentes de $\mathrm{CaO}$ não alterou $(\mathrm{P}>0,05)$ os tempos despendidos pelas vacas em ócio, ruminação e alimentação, mas promoveu incremento linear $(\mathrm{P}<0,05)$ sobre os tempos gastos com a ruminação de $1 \mathrm{~kg}$ de $\mathrm{MS}$ ou de FDN. A cana de açúcar picada e hidrolisada por $24 \mathrm{~h}$ com $0,5 \%$ a $2,0 \%$ de $\mathrm{CaO}$ não deve ser utilizada como volumoso exclusivo em dietas de vacas Holandês x Gir com produção de leite média de $10 \mathrm{~kg}$ $\operatorname{dia}^{-1}$.

Palavras-chave: Álcali. Bovino. Comportamento alimentar. Digestibilidade. Óxido de cálcio. Saccharum officinarum.

\section{Introduction}

The high production of dry matter (DM) of forage and a high content of soluble carbohydrates (sucrose) during the seasonal period of growth in tropical pastures makes sugarcane (Saccharum officinarum, L.) an important roughage resource for feeding cattle in milk production systems in Brazil (CASTRO et al., 2009; RESENDE; LEITE, 2016; CAMPOS et al., 2017).

However, sugarcane presents nutritional limitations that restrict its use as an exclusive ingredient in the diet of high-producing ruminants, such as the low crude protein $(\mathrm{CP})$ content in the DM of sugarcane forage (CAMPOS et al., 2017), which is on average $2.66 \%$ (VALADARES FILHO et al., 2010). The inclusion of nonprotein nitrogen sources, such as $1 \%$ urea (in fresh chopped sugarcane basis), in diets with $50 \%$ concentrates is a nutritional alternative for correcting the $\mathrm{CP}$ content of sugarcane, which, in addition to promoting a reduction in the costs of feeding cows, allows average milk yields of $22 \mathrm{~kg} \mathrm{day}^{-1}$ to be reached (SOUZA et al., 2015).

The neutral detergent fiber (NDF) content of sugarcane, which is on average $54.5 \% \mathrm{DM}$ (VALADARES FILHO et al., 2010), may be considered moderate when compared to the NDF content of forages of other tropical grasses (RIBEIRO et al., 2015; CAMPOS et al., 2017). However, sugarcane presents a comparatively high content of rumen-undegradable NDF that promotes a low ruminal digestion rate of the potentially degradable NDF (SANTOS et al., 2011). These fractions have a 
strong effect on rumen fill, being responsible for the observed reduction in the voluntary consumption of sugarcane-based diets, with a negative impact on the productive performance of cows (CORREA et al., 2003; SANTOS et al., 2011).

Potentially, hydrolysis with alkalinizing agents such as sodium hydroxide $(\mathrm{NaOH})$, calcium hydroxide $\left(\mathrm{Ca}(\mathrm{OH})_{2}\right)$ and calcium oxide $(\mathrm{CaO})$ may promote an increase in the digestibility of the fibrous fraction of sugarcane and consequently in the voluntary consumption of sugarcane-based diets, resulting in greater availability of nutrients for maintenance and production. In theory, these alkalis promote the breakdown of the cell wall and the partial solubilization of hemicelluloses, lignin and silica through the hydrolysis of uronic esters and acetic acid and the swelling of cellulose (JACKSON, 1977).

Only five studies have compared the effects of chopped sugarcane supplied in natura versus hydrolyzed on the voluntary consumption of nutrients and on the production and composition of cow's milk (CARVALHO, 2008; SFORCINI, 2009; ALVES et al., 2010; SILVA JÚNIOR et al., 2015; TEIXEIRA JUNIOR et al., 2015). Irrespective of the dose and the alkalizing agent used $(0.5 \%$ to $1 \% \mathrm{Ca}(\mathrm{OH})_{2}$ or $0.5 \%$ to $\left.2.25 \% \mathrm{CaO}\right)$, there was no effect of the chemical treatment of sugarcane on the DM intake of the diets. On the other hand, there was an increase in the milk yield of cows fed diets based on sugarcane hydrolyzed for $72 \mathrm{~h}$ with $0.5 \% \mathrm{CaO}$ (SFORCINI, 2009) or for $24 \mathrm{~h}$ with $1 \% \mathrm{Ca}(\mathrm{OH})_{2}$ (ALVES et al., 2010). Only Sforcini (2009) reported a difference in milk composition with the use of hydrolyzed sugarcane; the protein content was lower in the milk of cows that received sugarcane hydrolyzed for $72 \mathrm{~h}$ with $0.5 \% \mathrm{CaO}$. Thus, in view of the divergence of results, further studies on the supply of diets based on hydrolyzed sugarcane to lactating cows are necessary.

The aim of this study was to evaluate the voluntary consumption and digestibility of nutrients, the feeding behavior, and the milk production and composition of Holstein x Gyr dairy cows fed diets based on chopped sugarcane supplied in natura or hydrolyzed with $0.5 \%, 1 \%$ or $2 \% \mathrm{CaO}$.

\section{Material and Methods}

The study was carried out at Embrapa Dairy Cattle in Valença (RJ), Brazil. All experimental procedures with animals were carried out according to Embrapa Dairy Cattle guidelines for animal care and use in research.

A switchback design with three periods, four treatments, three blocks and twelve multiparous 7/8 Holstein x Gyr dairy cows past the peak of lactation was used. At the beginning of the experiment, the cows were producing an average of 12.1 \pm 3.0 $\mathrm{kg}$ day $^{-1}$ of milk and weighed $484 \pm 50 \mathrm{~kg}$. Each period comprised 21 days, with 14 and seven days, respectively, for adaptation to the diets and data collection. The cows were homogeneously allocated to the treatments and blocks based on milk production, days in milk and body weight as measured in the pre-experimental period. The animals were kept in tie stalls, each equipped with an individual trough and automatic drinking water fountain.

Four diets based on chopped sugarcane were evaluated as the only roughage (Table 1). The sugarcane was supplied in natura (control) or was first hydrolyzed (fresh matter basis) for $24 \mathrm{~h}$ with $0.5 \%, 1 \%$ or $2 \% \mathrm{CaO}$. The $\mathrm{CaO}$ was supplied by Ical (Indústria de Calcinação Ltda., Felixlândia, MG, Brazil) in microprocessed form with low levels of dioxins, furans and magnesium.

A concentrated supplement of $1 \mathrm{~kg}$ for every 10 $\mathrm{kg}$ of sugarcane (fresh matter basis) was provided in a total mixed ration (TMR). The diet was provided to the animals twice a day, at $08 \mathrm{~h} 00$ and $15 \mathrm{~h} 00$, and it was adjusted to allow for $15 \%$ orts on an as-fed basis, based on the intake of the previous day. The concentrate supplied had the following ingredient 
composition (as fed): 50\% soybean meal, 42\% corn meal, $5 \%$ urea:ammonium sulfate mixture (9:1), and $3 \%$ mineral supplement. The macroand micromineral concentrations of the mineral supplement and of $\mathrm{CaO}$ are shown in Table 2. The RB-73-9735 variety of sugarcane was used, which has an average productivity of forage (fresh matter) of over $150 \mathrm{t} \mathrm{ha}^{-1}$ year $^{-1}$, medium/late maturation, medium tillering and rare flowering (RESENDE; LEITE, 2016). The sugarcane presented a mean Brix value of $22^{\circ}$. The formulation of the experimental diets was based on the nutritional requirements of the cows, determined according to the NRC (2001).

Table 1. Chemical composition of the diets expressed in percentage of dry matter (\% DM).

\begin{tabular}{|c|c|c|c|c|}
\hline \multirow{2}{*}{ Nutrient (\% DM) } & \multicolumn{4}{|c|}{$\% \mathrm{CaO}$ added to sugarcane (fresh matter basis) } \\
\hline & 0.0 & 0.5 & 1.0 & 2.0 \\
\hline Dry matter (\%, fresh basis) & 33.18 & 33.38 & 34.52 & 35.34 \\
\hline Organic matter & 88.63 & 85.30 & 83.29 & 80.10 \\
\hline Ether extract (EE) & 1.40 & 1.33 & 1.13 & 0.98 \\
\hline Nonfibrous carbohydrates (NFC) ${ }^{1}$ & 46.13 & 43.33 & 42.91 & 41.22 \\
\hline NDFap $^{2}$ & 31.75 & 32.02 & 30.95 & 29.92 \\
\hline Acid detergent fiber & 23.27 & 19.53 & 20.77 & 19.84 \\
\hline Lignin & 4.71 & 3.39 & 4.03 & 3.62 \\
\hline Cellulose & 18.57 & 16.14 & 16.74 & 16.22 \\
\hline Hemicelluloses & 9.72 & 14.37 & 12.07 & 12.67 \\
\hline Crude protein $(\mathrm{CP})$ & 9.35 & 8.63 & 8.30 & 7.99 \\
\hline Mineral matter (MM) & 11.37 & 14.70 & 16.71 & 19.90 \\
\hline Calcium $(\mathrm{Ca})$ & 0.30 & 1.19 & 2.01 & 3.55 \\
\hline Phosphorus (P) & 0.19 & 0.18 & 0.20 & 0.20 \\
\hline Ratio Ca:P & 1.55 & 6.58 & 10.70 & 19.77 \\
\hline
\end{tabular}

${ }^{1} \mathrm{NFC}=100-(\% \mathrm{NDFap}+\% \mathrm{CP}+\% \mathrm{EE}+\% \mathrm{MM})$, according with Weiss (1999).

${ }^{2} \mathrm{NDF} a \mathrm{p}=$ Neutral detergent fiber corrected for ash and protein.

Table 2. Mineral composition of the mineral supplement and calcium oxide $(\mathrm{CaO})$.

\begin{tabular}{lcccccccc}
\hline \multirow{2}{*}{ Item } & \multicolumn{4}{c}{ Macromineral (\% DM) } & \multicolumn{4}{c}{ Micromineral (ppm) } \\
\cline { 2 - 9 } & $\mathrm{Ca}$ & $\mathrm{Mg}$ & $\mathrm{P}$ & $\mathrm{K}$ & $\mathrm{Cu}$ & $\mathrm{Zn}$ & $\mathrm{Fe}$ & $\mathrm{Mn}$ \\
\hline Mineral supplement & 9.6 & 1.0 & 8.7 & 0.08 & 1,254 & 4,228 & 5,258 & 427 \\
$\mathrm{CaO}$ & 44.5 & 0.3 & 2.9 & 0.05 & 41 & 73 & 1,388 & 128 \\
\hline
\end{tabular}

$\mathrm{Ca}=$ Calcium; $\mathrm{Mg}=$ Magnesium; $\mathrm{P}=$ Phosphorus; $\mathrm{K}=$ Potassium; $\mathrm{Cu}=\mathrm{Copper} ; \mathrm{Mn}=$ Manganese; $\mathrm{Fe}=\mathrm{Iron}$ and $\mathrm{Zn}=\mathrm{Zinc}$.

From the $15^{\text {th }}$ to the $20^{\text {th }}$ day of each switchback period, the voluntary intakes of each cow were measured as the difference between the daily quantities supplied and their individual orts. Samples of the TMR from each treatment were collected twice a day (before the morning and afternoon feedings) and stored $\left(-10^{\circ} \mathrm{C}\right)$ until chemical analysis. In addition, samples of the individual orts were collected daily in the morning and stored $\left(-10^{\circ} \mathrm{C}\right)$. After thawing, the feed and orts samples were dried in a forced-ventilation oven $\left(55^{\circ} \mathrm{C}\right)$ for $72 \mathrm{~h}$ and ground through a $1 \mathrm{~mm}$ screen (Wiley Mill; 
A. H. Thomas, Philadelphia, PA, USA). Feces and orts were pooled per animal by daily weight based on the $55^{\circ} \mathrm{C} \mathrm{DM}$.

Individual fecal DM production was estimated using chromic oxide - $\mathrm{Cr}_{2} \mathrm{O}_{3}$ (Óxido de Cromo III Puríssimo - Código 841, Vetec Química Fina Ltda., Duque de Caxias, RJ, Brazil) as an external marker at a rate of $12 \mathrm{~g} \mathrm{cow}^{-1} \mathrm{day}^{-1}$, administered orally and wrapped in paper for 11 days in two doses of $6 \mathrm{~g}$ each immediately after the milking. During the last five days of $\mathrm{Cr}_{2} \mathrm{O}_{3}$ administration, fecal samples were individually collected by rectal grabbing twice a day after the milking and stored $\left(-10^{\circ} \mathrm{C}\right)$ until chemical analysis. At the end of the experiment, the fecal samples were thawed, predried $\left(55^{\circ} \mathrm{C}, 72 \mathrm{~h}\right)$, milled $(5 \mathrm{~mm})$, and then pooled by cow $\mathrm{x}$ switchback period based on predried DM. Afterwards, the composite fecal samples were ground again to pass through a $1 \mathrm{~mm}$ screen and stored for later analysis of $\mathrm{Cr}$ content using atomic absorption spectrophotometry according to the INCT-CA M-005/1 method (DETMANN et al., 2012). Fecal DM production was determined by the ratio between the amount of the marker administered to the cow $\left(\mathrm{g} \mathrm{day}^{-1}\right)$ and its concentration in fecal DM, expressed as $\mathrm{g} \mathrm{kg}^{-1}$ (LOPES, 2007).

The samples of TMRs, orts and feces were analyzed in the Laboratory of Food Analysis of Embrapa Dairy Cattle (Juiz de Fora, MG, Brazil) for the contents of $\mathrm{DM}$ (at $105^{\circ} \mathrm{C}$ ), crude protein $(\mathrm{CP})$, ether extract (EE), mineral matter (MM), neutral detergent insoluble nitrogen (NIDN), NDF, acid detergent fiber (ADF) and lignin, and NDF corrected for ash and protein (NDFap), according to the methods described by Detmann et al. (2012). To analyze the calcium (Ca) and phosphorus (P) contents, a mineral solution was prepared according to the methodology described by Silva and Queiroz (2002). The Ca and P contents in these samples were determined in an atomic absorption spectrophotometer.
The in vivo digestibility coefficients of DM, organic matter (OM), NDFap and ADF were calculated, as described by Berchielli et al. (2011).

Cows were mechanically milked twice a day (07h00 and 14h00), and milk production was recorded for five consecutive days from the $15^{\text {th }}$ to the $19^{\text {th }}$ day of each switchback period. On the $15^{\text {th }}$ and $16^{\text {th }}$ day of each switchback period, aliquots of milk from each milking ( $2 / 3$ at morning milking + $1 / 3$ at afternoon milking) were collected to compose individual samples $(30 \mathrm{~mL})$ that were stored in flasks with bronopol preservative for subsequent analysis of protein, fat, lactose and total solids content via medium infrared spectrometry (Bentley 2300; Bentley Instruments Inc., Chaska, MN, USA) in the Milk Quality Laboratory of Embrapa Dairy Cattle (Juiz de Fora, MG, Brazil).

On the $17^{\text {th }}$ day of each switchback period, the feeding behavior of the cows was examined. The time spent feeding, ruminating and idle was assessed by visual observation for $24 \mathrm{~h}$ in 10-minute intervals (OLIVEIRA et al., 2007), and mean values were obtained for each activity. During the night, the feeding behavior of the cows was observed while keeping the environment under artificial lighting.

The results were analyzed according to a switchback design with four treatments and 12 cows in three blocks using the general linear model procedure of SAS v. 9.0. The model included effects for block, cow within block, period (linear) by cow within block, period (class variable) within block, and treatment, according to the model proposed by Sanders and Gaynor (1987). The linear and quadratic effects of the treatments were analyzed using orthogonal contrasts. As the levels of the treatments (\% $\mathrm{CaO}$ added to sugarcane) were not equally spaced, the ORPOL function in the CONTRAST statement in the Interactive Matrix Language (IML) procedure of SAS was used to create the orthogonal polynomial trend contrast coefficients. Results are reported as least squares means and effects were considered significant when $\mathrm{P} \leq 0.05$. 


\section{Results and Discussion}

Compared to that in the control treatment, the $\mathrm{Ca}$ concentration increased by $297 \%, 570 \%$ and $1,083 \%$ in the diets based on sugarcane hydrolyzed with $0.5 \%, 1 \%$ and $2 \% \mathrm{CaO}$, respectively, while the respective $\mathrm{Ca}: \mathrm{P}$ ratios were $6.58: 1,10.70: 1$ and 19.77:1 (control Ca:P ratio: 1.55:1) (Table 1). These increases were a consequence of the high $\mathrm{Ca}$ content in $\mathrm{CaO}$ (Table 2), which was also the main factor responsible for the increases in the MM and DM content of the diets with hydrolyzed sugarcane as well as the reductions in OM compared with those of the control treatment (Table 1). The results of the present study corroborate those presented by Daniel et al. (2013), who performed a meta-analysis study of 20 published articles and observed a reduction in $\mathrm{OM}$ content and an increase in the concentrations of $\mathrm{DM}, \mathrm{MM}$ and $\mathrm{Ca}$ in sugarcane hydrolyzed with $0.5 \%$ to $3 \% \mathrm{CaO}$.

On the other hand, since there was no change in the P content of the four diets evaluated (Table 1) and since both sugarcane and $\mathrm{CaO}$ present low concentrations of this mineral, the $\mathrm{Ca}: \mathrm{P}$ ratio, which in the control treatment was $1.55: 1$, increased to 19.77:1 in the diet including sugarcane hydrolyzed with $2 \% \mathrm{CaO}$ (Table 1), an increase of $1,176 \%$. Significant increases in the $\mathrm{Ca}: \mathrm{P}$ ratio due to sugarcane hydrolysis with $\mathrm{CaO}$ were also observed by Domingues et al. (2014) and Chizzotti et al. (2015), who reported Ca:P ratios of 1.85:1 to 1.95:1 for chopped fresh sugarcane and ratios of 4.29:1 to $36.46: 1$ for sugarcane hydrolyzed with $0.5 \%$ to $2 \% \mathrm{CaO}$. Wise et al. (1963) evaluated the effect of Ca:P ratios ranging from $0.4: 1$ to $14.3: 1$ on voluntary intake and weight gain in growing cattle $(114 \mathrm{~kg})$. These authors concluded that diets with Ca:P ratios ranging from 1:1 to $7.1: 1$ did not impair the growth of the animals, presenting similar performance results. In the present study (Table 1), diets including sugarcane hydrolyzed with $1 \%$ and $2 \% \mathrm{CaO}$ presented $\mathrm{Ca}: \mathrm{P}$ ratios well above the upper limit of this range, which was considered optimal by Wise et al. (1963) and by the NRC (2001).
There was a linear increase $(\mathrm{P}<0.01)$ in the intake of $\mathrm{MM}$ and $\mathrm{Ca}$ in response to the amount of $\mathrm{CaO}$ used for hydrolysis of sugarcane. In comparison with the $\mathrm{Ca}$ intake in the control group cows, an increase in Ca intake of more than $460 \%$ was observed for the cows that received the diet based on sugarcane hydrolyzed with $2 \% \mathrm{CaO}$ (Table 3 ). Considering the $\mathrm{Ca}$ absorption coefficient of 0.38 recommended by the NRC (2001) and the Ca absorption requirements for maintenance $\left(0.0031 \mathrm{~g} \mathrm{~kg}\right.$ body weight $\left.^{-1}\right)$ and production $\left(1.37 \mathrm{~g} \mathrm{~kg} \mathrm{milk}^{-1}\right)$, the cows receiving diets including sugarcane hydrolyzed with $0 \%$, $0.5 \%, 1 \%$ and $2 \% \mathrm{CaO}$ presented absorbed $\mathrm{Ca}$ intake that was $25 \%, 170 \%, 359 \%$ and $719 \%$ greater than their requirements, respectively. According to the NRC (2001), excessive intake of Ca can interfere with trace mineral absorption (especially zinc absorption) and can replaces energy or protein that could be used by the animal to increase production.

The hydrolysis of sugarcane with increasing amounts of $\mathrm{CaO}$ promoted a linear reduction $(\mathrm{P}<0.01)$ in $\mathrm{DM}$ intake and, consequently, a linear reduction in the consumption of nonfibrous carbohydrates (NFC), CP, OM, NDFap and EE (Table 3). In addition to the reductions in DM intake, reductions were generally observed in the contents of these nutrients as sugarcane hydrolyzed with higher amounts of $\mathrm{CaO}$ was included in the experimental diets (Table 1), which also contributed to a decrease in the consumption of these fractions. The reduction observed in the $\mathrm{OM}$ content in hydrolyzed sugarcane-based diets was directly associated with the increase in the MM content due to the use of $\mathrm{CaO}$ in sugarcane hydrolysis, which also caused a dilution effect, reducing the concentrations of other nutrients such as NFC, EE and CP (Table 1). In this sense, in relation to that of the control diet, there were substantial increases in MM content of $29 \%, 47 \%$ and $75 \%$, respectively, when $0.5 \%, 1 \%$ and $2 \% \mathrm{CaO}$ was used in the sugarcane hydrolysis (Table 1). Moreover, the heat resulting from the $\mathrm{CaO}$ hydration reaction in the forage submitted to hydrolysis can accelerate 
the sugarcane fermentation process, reducing the NFC content (DANIEL et al., 2013).

soluble carbohydrate content and, consequently, the

Table 3. Nutrient intake in lactating Holstein $x$ Gyr cows fed sugarcane-based diets hydrolyzed with calcium oxide $(\mathrm{CaO})$.

\begin{tabular}{|c|c|c|c|c|c|c|c|}
\hline \multirow{2}{*}{ Item } & \multicolumn{4}{|c|}{$\begin{array}{l}\text { \% } \mathrm{CaO} \text { added to sugarcane } \\
\text { (fresh matter basis) }\end{array}$} & \multirow{2}{*}{$\begin{array}{l}\text { Standard } \\
\text { error of the } \\
\text { mean }\end{array}$} & \multicolumn{2}{|c|}{ P-value } \\
\hline & 0.0 & 0.5 & 1.0 & 2.0 & & Linear & Quadratic \\
\hline \multicolumn{8}{|l|}{$\mathrm{kg} \mathrm{cow}^{-1}$ day $^{-1}$} \\
\hline Dry matter $(\mathrm{DM})$ & 11.44 & 10.41 & 9.51 & 8.40 & 0.2981 & 0.0004 & 0.3114 \\
\hline Organic matter & 10.14 & 8.91 & 7.94 & 6.72 & 0.2309 & $<0.0001$ & 0.1229 \\
\hline Crude protein $(\mathrm{CP})$ & 1.04 & 0.86 & 0.82 & 0.70 & 0.0557 & 0.0069 & 0.3344 \\
\hline Nonfibrous carbohydrates (NFC) ${ }^{1}$ & 5.25 & 4.51 & 4.08 & 3.45 & 0.1393 & 0.0001 & 0.1227 \\
\hline Total digestible nutrients & 8.06 & 6.70 & 5.94 & 5.02 & 0.2170 & $<0.0001$ & 0.0457 \\
\hline NDFap $^{2}$ & 3.40 & 3.14 & 2.73 & 2.36 & 0.0826 & 0.0001 & 0.3042 \\
\hline Ether extract (EE) & 0.18 & 0.14 & 0.12 & 0.09 & 0.0087 & 0.0005 & 0.2103 \\
\hline Acid detergent fiber & 2.68 & 1.91 & 1.91 & 1.62 & 0.0688 & $<0.0001$ & 0.0015 \\
\hline Lignin & 0.53 & 0.30 & 0.38 & 0.30 & 0.0108 & $<0.0001$ & 0.0005 \\
\hline Hemicelluloses & 0.85 & 1.42 & 0.98 & 0.94 & 0.0437 & 0.1920 & 0.0023 \\
\hline Cellulose & 2.14 & 1.61 & 1.54 & 1.33 & 0.0584 & 0.0001 & 0.0087 \\
\hline Mineral matter (MM) & 1.34 & 1.53 & 1.58 & 1.71 & 0.0329 & 0.0003 & 0.0882 \\
\hline Phosphorus (P) & 0.0223 & 0.0198 & 0.0179 & 0.0167 & 0.0018 & 0.0760 & 0.4956 \\
\hline Calcium $(\mathrm{Ca})$ & 0.0544 & 0.1182 & 0.1901 & 0.3051 & 0.0087 & $<0.0001$ & 0.4771 \\
\hline \multicolumn{8}{|l|}{$\mathrm{kg} 100 \mathrm{~kg}$ body weight ${ }^{-1}$} \\
\hline DM & 2.33 & 2.11 & 1.96 & 1.78 & 0.0503 & 0.0003 & 0.1513 \\
\hline $\mathrm{NDFap}^{2}$ & 0.69 & 0.64 & 0.56 & 0.50 & 0.0140 & $<0.0001$ & 0.1619 \\
\hline
\end{tabular}

${ }^{1} \mathrm{NFC}=100-(\% \mathrm{NDFap}+\% \mathrm{CP}+\% \mathrm{EE}+\% \mathrm{MM})$, according with Weiss (1999).

${ }^{2} \mathrm{NDF} a \mathrm{p}=$ Neutral detergent fiber corrected for ash and protein.

The intake of total digestible nutrients (TDN), ADF, lignin, hemicelluloses and cellulose presented quadratic behavior $(\mathrm{P}<0.01)$ in response to the increase in $\mathrm{CaO}$ inclusion (Table 3). This result may be a consequence of the increase in the fibrous fraction concentrations in response to the loss of NFC caused by the possible fermentation of the sugarcane forage treated with $\mathrm{CaO}$. In this sense, in relation to that of the control treatment, the NFC content was reduced by $11 \%$ in the diet including sugarcane hydrolyzed with $2 \% \mathrm{CaO}$ (Table 1). Carvalho (2008) also observed quadratic behavior for TDN intake in diets supplied to lactating cows that were based on chopped sugarcane supplied in natura or hydrolyzed with up to $2.25 \% \mathrm{CaO}$. In the present study, the minimum TDN intake value of $5.48 \mathrm{~kg} \mathrm{cow}^{-1}$ day $^{-1}$ was estimated when $2.0 \% \mathrm{CaO}$ was used in sugarcane hydrolysis.

The absence of an effect on NDFap digestibility $(\mathrm{P}>0.05)$ and the linear reductions $(\mathrm{P}<0.05)$ observed in $\mathrm{DM}, \mathrm{OM}$ and $\mathrm{ADF}$ digestibility in response to the increase in the amount of $\mathrm{CaO}$ used in sugarcane hydrolysis (Table 4) indicate that treatment with this alkaline agent did not reach the objective of altering the chemical composition of the sugarcane fibrous fractions to increase its digestibility and, consequently, the voluntary intake of diets based on this roughage. Thus, consistent with the findings 
of Carvalho (2008), it can be said that $\mathrm{CaO}$ does not constitute a promising alkaline agent for the treatment of sugarcane for lactating cows, since there was no positive effect of sugarcane hydrolysis on digestibility (Table 4) and, consequently, on the intake of the diets (Table 3). In general, this is the result that has been systematically observed in the few studies performed on lactating cows fed diets based on sugarcane hydrolyzed with $\mathrm{CaO}$. Illustrating this, Carvalho (2008) and Silva Júnior et al. (2015) did not observe a positive effect $(\mathrm{P}>0.05)$ of sugarcane hydrolysis for $24 \mathrm{~h}$ with $0.75 \%$ to $2.25 \% \mathrm{CaO}$ on the digestibility of $\mathrm{DM}$, OM, CP, NDF and TDN. Similarly, there was no effect $(\mathrm{P}>0.05)$ on DM, CP, NDF, NDFap, ADF and TDN intake in diets based on sugarcane hydrolyzed for up to $48 \mathrm{~h}$ with $0.5 \%$ to $2 \% \mathrm{CaO}$ (CARVALHO, 2008; SFORCINI, 2009; SILVA JÚNIOR et al., 2015; TEIXEIRA JUNIOR et al., 2015).

Table 4. Nutrient digestibility in lactating Holstein x Gyr cows fed sugarcane-based diets hydrolyzed with calcium oxide $(\mathrm{CaO})$.

\begin{tabular}{|c|c|c|c|c|c|c|c|}
\hline \multirow[t]{2}{*}{ Digestitility (\%) } & \multicolumn{4}{|c|}{$\begin{array}{l}\% \mathrm{CaO} \text { added to sugarcane } \\
\text { (fresh matter basis) }\end{array}$} & \multirow{2}{*}{$\begin{array}{l}\text { Standard error } \\
\text { of the mean }\end{array}$} & \multicolumn{2}{|c|}{ P-value } \\
\hline & 0.0 & 0.5 & 1.0 & 2.0 & & Linear & Quadratic \\
\hline Dry matter & 76.89 & 72.16 & 70.25 & 66.15 & 1.2236 & 0.0011 & 0.2956 \\
\hline Organic matter & 78.76 & 74.78 & 73.74 & 70.62 & 1.4745 & 0.0114 & 0.4565 \\
\hline NDFap $^{1}$ & 51.54 & 44.40 & 40.73 & 41.01 & 3.9019 & 0.1345 & 0.2678 \\
\hline Acid detergent fiber & 52.50 & 31.85 & 38.55 & 29.63 & 4.2070 & 0.0239 & 0.1973 \\
\hline
\end{tabular}

${ }^{1} \mathrm{NDF} a \mathrm{p}=$ Neutral detergent fiber corrected for ash and protein.

As a direct reflection of the reduction in nutrient intake and digestibility of the diets in response to sugarcane hydrolysis with increasing amounts of $\mathrm{CaO}$ (Tables 3 and 4), there were linear reductions $(\mathrm{P}<0.05)$ in milk production corrected or not corrected to $4 \%$ fat and in protein, lactose and total solids content (Table 5). Because of this, linear reductions $(\mathrm{P}<0.05)$ were also observed in the production of all milk components. Only the milk fat content was not altered $(\mathrm{P}>0.05)$ in response to the inclusion of hydrolyzed sugarcane in the diets (Table 5). In studies on lactating cows evaluating diets based on sugarcane hydrolyzed up to $48 \mathrm{~h}$ with $0.5 \%$ to $2.25 \% \mathrm{CaO}$, there were no differences $(\mathrm{P}>0.05)$ in milk yield or in the content of protein, fat, lactose and total solids in relation to those obtained with the control diets based on chopped fresh sugarcane. However, in a study carried out with $1 \% \mathrm{Ca}(\mathrm{OH})_{2}$ as an alkaline agent, Alves et al. (2010) reported a positive effect of sugarcane hydrolysis on milk production, while Sforcini (2009) used sugarcane hydrolyzed for $72 \mathrm{~h}$ with $0.5 \% \mathrm{CaO}$ and observed an increase in milk yield and a reduction in milk protein content. These were the only studies on lactating cows in which there was any change in milk production or composition due to the inclusion of hydrolyzed sugarcane. The milk yields and compositions observed in the present study are within the ranges reported in previous studies in which sugarcane hydrolyzed with $\mathrm{CaO}$ was supplied to lactating cows: 7.29$19.98 \mathrm{~kg}$ milk cow $^{-1}$ day $^{-1}$ with $2.96 \%-3.41 \%$ protein, $3.23 \%-4.32 \%$ fat, $4.09 \%-5.63 \%$ lactose, and $11.22 \%-13.00 \%$ total solids (CARVALHO, 2008; SFORCINI, 2009; SILVA JÚNIOR et al., 2015; TEIXEIRA JUNIOR et al., 2015).

There was a quadratic effect $(\mathrm{P}=0.0233)$ of sugarcane hydrolysis with $\mathrm{CaO}$ on feed efficiency expressed in $\mathrm{kg}$ of milk per $\mathrm{kg}$ of DM consumed (Table 5). The maximum value of 1.09 for feed 
efficiency was estimated when $1.3 \% \mathrm{CaO}$ was used for sugarcane hydrolysis. The observed values for $\mathrm{kg}$ of milk per $\mathrm{kg}$ of DM consumed are situated in the range of 0.68 to 1.25 reported by Carvalho (2008) and Silva Júnior et al. (2015). In these studies, Carvalho (2008) did not observe an effect $(\mathrm{P}>0.05)$ of sugarcane hydrolysis with $0.5 \%$ to $2.25 \% \mathrm{CaO}$ on feed efficiency, whereas Silva Júnior et al. (2015) evaluated diets with added urea and reported higher feed efficiency $(\mathrm{P}<0.05)$ in the diet with hydrolyzed sugarcane than in that with chopped fresh sugarcane.

Table 5. Performance and milk composition in Holstein x Gyr cows fed sugarcane-based diets hydrolyzed with calcium oxide $(\mathrm{CaO})$.

\begin{tabular}{|c|c|c|c|c|c|c|c|}
\hline \multirow[t]{2}{*}{ Item } & \multicolumn{4}{|c|}{$\begin{array}{l}\% \mathrm{CaO} \text { added to sugarcane } \\
\text { (fresh matter basis) }\end{array}$} & \multirow{2}{*}{$\begin{array}{l}\text { Standard } \\
\text { error of } \\
\text { the mean }\end{array}$} & \multicolumn{2}{|c|}{ P-value } \\
\hline & 0.0 & 0.5 & 1.0 & 2.0 & & Linear & Quadratic \\
\hline \multicolumn{8}{|l|}{ Yield } \\
\hline Milk $\left(\mathrm{kg} \mathrm{day}^{-1}\right)$ & 10.92 & 11.02 & 10.38 & 9.26 & 0.3196 & 0.0075 & 0.3304 \\
\hline $\mathrm{FCM}^{1}\left(\mathrm{~kg} \mathrm{day}^{-1}\right)$ & 10.50 & 10.26 & 9.64 & 8.45 & 0.4223 & 0.0124 & 0.6766 \\
\hline Protein $\left(\mathrm{g} \mathrm{day}^{-1}\right)$ & 340.0 & 333.6 & 312.9 & 277.1 & 9.4368 & 0.0028 & 0.5828 \\
\hline Fat $\left(\mathrm{g} \mathrm{day}^{-1}\right)$ & 409.0 & 390.2 & 366.2 & 316.4 & 20.5083 & 0.0186 & 0.8724 \\
\hline Lactose $\left(\right.$ g day $\left.^{-1}\right)$ & 477.6 & 479.2 & 443.6 & 393.5 & 13.4547 & 0.0032 & 0.4122 \\
\hline Solids-not-fat $\left(\mathrm{g} \mathrm{day}^{-1}\right)$ & 932.9 & 926.9 & 862.6 & 763.8 & 25.9549 & 0.0028 & 0.4744 \\
\hline Total solids $\left(\mathrm{g} \mathrm{day}^{-1}\right)$ & $1,341.9$ & $1,317.1$ & $1,228.8$ & $1,080.2$ & 44.9282 & 0.0053 & 0.6235 \\
\hline \multicolumn{8}{|l|}{ Milk composition (\%) } \\
\hline Protein & 3.12 & 3.04 & 3.02 & 3.00 & 0.0243 & 0.0181 & 0.1606 \\
\hline Fat & 3.77 & 3.55 & 3.51 & 3.44 & 0.1065 & 0.1071 & 0.3852 \\
\hline Lactose & 4.38 & 4.37 & 4.27 & 4.23 & 0.0332 & 0.0125 & 0.6482 \\
\hline Solids-not-fat & 8.56 & 8.45 & 8.32 & 8.24 & 0.0411 & 0.0016 & 0.1675 \\
\hline Total solids & 12.33 & 11.99 & 11.82 & 11.68 & 0.1163 & 0.0103 & 0.2085 \\
\hline \multicolumn{8}{|l|}{ Feed efficiency } \\
\hline $\mathrm{kg}$ of milk/kg of dry matter intake & 0.95 & 1.08 & 1.11 & 1.10 & 0.0264 & 0.0132 & 0.0233 \\
\hline $\mathrm{kg}$ of FCM/kg of dry matter intake & 0.92 & 1.00 & 1.03 & 1.01 & 0.0312 & 0.1250 & 0.1123 \\
\hline
\end{tabular}

${ }^{1} \mathrm{FCM}=4 \%$ fat-corrected milk $(\mathrm{NRC}, 2001)=0.4 *$ MilkProduction $+15 *(\%$ MilkFat $/ 100) *$ MilkProduction.

There was no effect $(\mathrm{P}>0.05)$ of sugarcane hydrolysis with increasing amounts of $\mathrm{CaO}$ on the time spent (minutes day ${ }^{-1}$ ) by cows idle, ruminating or feeding, nor was there an effect in the time spent feeding $1 \mathrm{~kg}$ of DM and NDF (Table 6). The absence of an effect of sugarcane hydrolysis on rumination activity (Table 6), combined with the lower DM and NDF intakes observed in cows fed hydrolyzed sugarcane-based diets (Table 3 ) promoted a linear increase $(\mathrm{P}<0.05)$ in the time spent ruminating 1 $\mathrm{kg}$ of DM and NDF (Table 6). Compared to the cows in the control treatment, those fed sugarcane hydrolyzed with $2 \% \mathrm{CaO}$ took $38 \%$ and $46 \%$ longer to ruminate $1 \mathrm{~kg}$ of $\mathrm{DM}$ and $\mathrm{NDF}$, respectively. These results indicate that hydrolysis with $\mathrm{CaO}$ did not reach the objective of reducing the fibrous fractions of sugarcane. To reinforce this hypothesis, in a companion study performed concomitantly with the present study, Campos et al. (2011) did not observe any effects of the inclusion of $1 \%$ or $2 \%$ $\mathrm{CaO}$ on in situ ruminal degradability of the fibrous fractions (NDF and ADF) of hydrolyzed sugarcane. 
Table 6. Feeding behavior in lactating Holstein x Gyr cows fed sugarcane-based diets hydrolyzed with calcium oxide $(\mathrm{CaO})$.

\begin{tabular}{|c|c|c|c|c|c|c|c|}
\hline \multirow[t]{2}{*}{ Item } & \multicolumn{4}{|c|}{$\begin{array}{l}\% \mathrm{CaO} \text { added to sugarcane } \\
\text { (fresh matter basis) }\end{array}$} & \multirow{2}{*}{$\begin{array}{l}\text { Standard } \\
\text { error of the } \\
\text { mean }\end{array}$} & \multicolumn{2}{|c|}{ P-value } \\
\hline & 0.0 & 0.5 & 1.0 & 2.0 & & Linear & Quadratic \\
\hline \multicolumn{8}{|c|}{ Activity (minutes day ${ }^{-1}$ ) } \\
\hline Idle & 465.8 & 453.9 & 488.9 & 527.0 & 27.1972 & 0.1226 & 0.6524 \\
\hline Rumination & 526.3 & 570.1 & 558.2 & 533.2 & 26.7899 & 0.9144 & 0.3025 \\
\hline Feeding & 331.9 & 301.9 & 278.8 & 277.5 & 20.2777 & 0.1241 & 0.3433 \\
\hline \multicolumn{8}{|c|}{ Time spent ruminating $1 \mathrm{~kg}$ of dry matter (DM) and neutral detergent fiber (NDF) } \\
\hline Minutes $\mathrm{kg}^{-1}$ of DM & 45.9 & 54.7 & 58.4 & 63.4 & 3.1873 & 0.0110 & 0.2959 \\
\hline Minutes $\mathrm{kg}^{-1}$ of NDF & 154.2 & 180.7 & 203.5 & 225.8 & 11.3313 & 0.0049 & 0.3758 \\
\hline \multicolumn{8}{|c|}{ Time spent feeding $1 \mathrm{~kg}$ of dry matter (DM) and neutral detergent fiber (NDF) } \\
\hline Minutes $\mathrm{kg}^{-1}$ of DM & 29.7 & 28.9 & 29.2 & 33.4 & 2.1011 & 0.2270 & 0.3869 \\
\hline Minutes $\mathrm{kg}^{-1}$ of NDF & 100.3 & 95.5 & 101.5 & 119.3 & 7.3333 & 0.0866 & 0.3199 \\
\hline
\end{tabular}

\section{Conclusion}

Chopped sugarcane hydrolyzed for $24 \mathrm{~h}$ with $0.5 \%$ to $2.0 \% \mathrm{CaO}$ should not be used as exclusive roughage in diets for Holstein x Gyr dairy cows with an average milk production of $10 \mathrm{~kg} \mathrm{day}^{-1}$.

\section{Acknowledgments}

To Veterinary School of UFMG, Embrapa Dairy Cattle, Fapemig, CNPq, Ical (Indústria de Calcinação Ltda.) and Prodap for the financial support.

\section{References}

ALVES, A. C. N.; EZEQUIEL, J. M. B.; LIMA, M. L. P.; AUGUSTINHO, E. T. Desempenho produtivo de vacas mestiças alimentadas com cana-de-açúcar hidrolisada e in natura. Nucleus Animalium, Ituverava, v. 2, n. 2, p. 99-105, 2010.

BERCHIELLI, T. T.; VEJA-GARCIA, A.; OLIVEIRA, S. G. Principais técnicas de avaliação aplicadas em estudo de nutrição. In: BERCHIELLI, T. T.; PIRES, A. V.; OLIVEIRA, S. G. (Ed.). Nutrição de ruminantes. 2. ed. Jaboticabal: Funep, 2011. p. 415-438.

CAMPOS, M. M.; BORGES, A. L. C. C.; LOPES, F.
C. F.; PANCOTI, C. G.; SILVA, R. R. Degradabilidade in situ da cana-de-açúcar tratada ou não com óxido de cálcio, em novilhas leiteiras Holandês x Gir. Arquivo Brasileiro de Medicina Veterinária e Zootecnia, Belo Horizonte, v. 63, n. 6, p. 1487-1492, 2011.

CAMPOS, M. M.; LOPES, F. C. F.; PEREIRA, L. G. R.; MACHADO, F. S.; TOMICH, T. R. Cana-de-açúcar na alimentação de rebanhos leiteiros. In: SILVA, F. C.; ALVES, B. J. R.; FREITAS, P. L. (Ed.). Sistema de produção mecanizada da cana-de-açúcar integrada à produção de energia e alimentos. Brasília: EMBRAPA, 2017. v. 2, p. 900-938.

CARVAlHO, G. G. P. Cana-de-açúcar tratada com óxido de cálcio em dietas para ovinos, caprinos, novilhas e vacas em lactação. 2008. Tese (Doutorado em Zootecnia) - Universidade Federal de Viçosa, Viçosa, MG. Disponível em: <http://www.locus.ufv.br/ handle/123456789/1720>. Acesso em: 13 ago. 2018.

CASTRO, H. S.; ANDRADE, L. A. B.; BOTREL, E. P.; EVANGELISTA, A. R. Rendimentos agrícola e forrageiro de três cultivares de cana-de-açúcar (Saccharum spp.) em diferentes épocas de corte. Ciência e Agrotecnologia, Lavras, v. 33, n. 5, p. 1336-1341, 2009.

CHIZZOTTI, F. H. M.; PEREIRA, O. G.; VALADARES FILHO, S. C.; CHIZZOTTI, M. L.; RODRIGUES, R. T. S.; TEDESCHI, L. O.; SILVA, T. C. Does sugarcane ensiled with calcium oxide affect intake, digestibility, performance, and microbial efficiency in beef cattle? Animal Feed Science and Technology, Amsterdan, v. 203, p. 23-32, may 2015. 
CORREAA, C. E. S.; PEREIRA, M. N.; OLIVEIRA, S. G.; RAMOS, M. H. Performance of Holstein cows fed sugarcane or corn silages of different grain textures. Scientia Agricola, Piracicaba, v. 60, n. 4, p. 621-629, 2003.

DANIEL, J. L. P.; SANTOS, M. C.; ZOPOLLATTO, M.; HUHTANEN, P.; NUSSIO, L. G. A data-analysis of lime addition on the nutritive value of sugarcane in Brazil. Animal Feed Science and Technology, Amsterdan, v. 184, n. 1-4, p. 17-23, 2013.

DETMANN, E.; VALADARES FILHO, S. C.; BERCHIELLI, T. T.; CABRAL, L. S.; LADEIRA, M. M.; SOUZA, M. A.; QUEIROZ, A. C.; SALIBA, E. O. S.; PINA, D. P.; AZEVEDO, J. A. G. Métodos para análise de alimentos. Visconde do Rio Branco: Suprema, 2012. $214 \mathrm{p}$.

DOMINGUES, F. N.; OLIVEIRA, M. Dal S.; MOTA, D. A.; OLIVEIRA, R. P.; SANTOS, J.; MIRANDA, A. S.; GODOY, B. S. Composição mineral da cana-de-açúcar in natura hidrolisada com cal virgem $(\mathrm{CaO})$. Revista Brasileira de Saúde e Produção Animal, Salvador, v. 15, n. 4, p. 827-834, 2014.

JACKSON, M. G. Review article: the alkali treatment of straws. Animal Feed Science and Technology, Amsterdan, v. 2, n. 2, p. 105-130, 1977.

LOPES, F. C. F. Determinação do consumo de forrageiras tropicais por vacas em lactação em condição de pastejo. Cadernos Técnicos de Veterinária e Zootecnia, Belo Horizonte, v. 52, p. 1-116, abr. 2007.

NATIONAL RESEARCH COUNCIL - NRC. Nutrients requirements of dairy cattle. $7^{\text {th }}$ ed. Washington: National Academy Press, 2001. 381 p.

OLIVEIRA, A. S.; CAMPOS, J. M. S.; VALADARES FILHO, S. C.; ASSIS, A. J.; TEIXEIRA, R. M. A.; RENNÓ, L. N.; PINA, D. S.; OLIVEIRA, G. S. Substituição do milho pela casca de café ou de soja em dietas para vacas leiteiras: comportamento ingestivo, concentração de nitrogênio ureico no plasma e no leite, balanço de compostos nitrogenados e produção de proteína microbiana. Revista Brasileira de Zootecnia, Viçosa, MG, v. 36, n. 1, p. 205-215, 2007.

RESENDE, H.; LEITE, J. L. B. Tecnologia e custo da cana-de-açúcar para a alimentação animal. Juiz de Fora: EMBRAPA Gado de Leite, 2016. 16 p. (Série EMBRAPA Gado de Leite, Comunicado Técnico, 80). Disponível em: <https://ainfo.cnptia.embrapa.br/digital/ bitstream/item/155437/1/COT-80-Tecnologia-e-Custoda-Cana-de-acucar-para-a-Alimentacao-Animal.pdf $>$. Acesso em: 5 abr. 2018.
RIBEIRO, R. C. O.; VILLELA, S. D. J.; VALADARES FILHO, S. C.; SANTOS, S. A.; RIBEIRO, K. G.; DETMANN, E.; ZANETTI, D.; MARTINS, P. G. M. A. Effects of roughage sources produced in a tropical environment on forage intake, and ruminal and microbial parameters. Journal of Animal Science, Champaign, v. 93, n. 5, p. 2363-2374, 2015.

SANDERS, W. L.; GAYNOR, P. J. Analysis of switchback data using Statistical Analysis System, Inc. ${ }^{\circledR}$ software. Journal of Dairy Science, Champaign, v. 70, n. 10, p. 2186-2191, 1987.

SANTOS, S. A.; VALADARES FILHO, S. C.; DETMANN, E.; VALADARES, R. F. D.; RUAS, J. R. M.; AMARAL, P. M. Different forage sources for F1 Holstein x Gir dairy cows. Livestock Science, Amsterdan, v. 142, n. 1-3, p. 48-58, 2011.

SFORCINI, M. P. R. Silagem de milho, cana-de-açúcar in natura e hidrolisada, para vacas em lactação. 2009. Dissertação (Mestrado em Zootecnia) - Universidade Estadual Paulista, Faculdade de Ciências Agrárias e Veterinárias, Jaboticabal. Disponível em: $<\mathrm{https}: / / a l s a f i$. ead.unesp.br/handle/11449/96580>. Acesso em: 13 ago. 2018.

SILVA, D. J.; QUEIROZ, A. C. Análise de alimentos: métodos químicos e biológicos. 3. ed. Viçosa, MG: UFV, 2002. $235 \mathrm{p}$.

SILVA JÚNIOR, B. A.; OLIVEIRA, M. V. M.; MALTEMPI FILHO, P.; LUZ, D. F.; STERZA, F. A. M.; VARGAS JUNIOR, F. M.; BIAZOLLI, W. Desempenho de vacas leiteiras alimentadas com cana de açúcar associada à ureia e tratada com cal virgem na região do Alto Pantanal Sul-Mato-Grossense. Semina: Ciências Agrárias, Londrina, v. 36, n. 3, p. 2317-2328, 2015. Suplemento 1.

SOUZA, R. C.; REIS, R. B.; LOPEZ, F.C.F.; MOURTHE, M. H. F.; LANA, A. M. Q.; BARBOSA, F. A.; SOUSA, B. M. Efeito da adição de teores crescentes de ureia na cana-de-açúcar em dietas de vacas em lactação sobre a produção e composição do leite e viabilidade econômica. Arquivo Brasileiro de Medicina Veterinária e Zootecnia, Belo Horizonte, v. 67, n. 2, p. 564-572, 2015.

TEIXEIRA JUNIOR, D.; MISSIO, R. L.; SFORCINI, M. P. R.; OLIVEIRA, M. D. S.; FERRARI, V. B.; SANTOS, R. F. Productive performance of dairy cows fed with hydrolyzed sugarcane. Ciência Rural, Santa Maria, v. 45, n. 10, p. 1848-1853, 2015.

VALADARES FILHO, S. C.; MACHADO, P. A. S.; CHIZZOTTI, M. L.; AMARAL, H. B.; MAGALHÃES, K. A.; ROCHA JÚNIOR, V. C.; CAPELLE, E. R. (Ed.). Tabelas brasileiras de composição de alimentos para bovinos. 3. ed. Viçosa, MG: UFV/DZO, 2010. 502 p. 
WEISS, W. P. Energy prediction equations for ruminant feeds. In: CORNELL NUTRITION CONFERENCE FOR FEED MANUFACTORERS, 61., 1999, Ithaca. Proceedings... Ithaca: Cornell University, 1999. p. 176185.
WISE, M. B.; ORDOVEZA, A. L.; BARRICK, E. R. Influence of variations in dietary Calcium:Phosphorus ratio on performance and blood constituents of calves. The Journal of Nutrition, Cambridge, v. 79, n. 1, p. 7984, 1963. 